\title{
Kokemus toisesta ja kesto Bergsonin filosofiassa
}

\author{
KATJA CASTILLO \& MINNA-KERTTU KEKKI
}

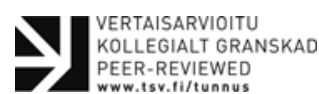

ABSTRAKTı Liittyessään kaikkeen inhimilliseen kokemukseen keston käsite liittyy myös välttämättä kokemukseen toisesta henkilöstä. Tätä näkökulmaa Bergsonin kokemuksen konstituution hahmottamisesta on kuitenkin tutkittu vähän. Kysymys kuuluu, voisiko Bergsonin keston käsitteellä luonnehtia kokemusta toisesta henkilöstä juuri toisena eri tavoin, kuin miten tilallisuuteen tai kehollisuuteen keskittyvät analyysit sitä kuvaavat. Argumentoimme, että Bergsonin keston käsite avaa kokemusta toisesta ainutlaatuisella tavalla, joka jää saavuttamatta muissa toiseuden analyyseissa, mutta joka on kuitenkin tärkeä näkökulma toisen erillisyyden sekä yhteneväisyyden mahdollisuuksien ymmärtämiselle ylittäen kokemuksen nyt-hetken.

\section{Johdanto}

Kesto (la durée), koettu ajallisuus laadullisena moninaisuutena ja toisiinsa punoutuvina jatkumoina, on Bergsonin filosofian keskeisiä käsitteitä. Liittyessään kaikkeen inhimilliseen kokemukseen keston käsite liittyy myös välttämättä kokemukseen toisesta henkilöstä. Tätä näkökulmaa Bergsonin kokemuksen konstituution hahmottamisesta on kuitenkin tutkittu vähän. Bergson ei itsekään analysoinut kokemusta toisesta henkilöstä kattavasti tai syvällisesti keston käsitteen näkökulmasta. Bergsonin eksplisiittiset näkökulmat kyseiseen kokemukseen ovat enimmäkseen tutkimusta toisen henkilön vapaudesta tai sympatiasta toista kohtaan, jotka tosin monimutkaisuudessaan liittyvät myös keston kysymyksiin: toisen ennakoimattomuuteen ja toisen uniikista henkilöhistoriasta johtuvaan kykenemättömyy- teen toisintaa toisen henkilön kokemusta (Bergson 1920a, 141-144). Vapaus ja sympatia (myös moraali, jota Bergson tutki toisissa yhteyksissä, ks. Bergson 1932) toki kuuluvat kokemuksen piiriin toisesta henkilöstä, mutta kyseinen kokemus sinänsä on paljon muutakin kuin toisen henkilön vapautta minun päätäntävallastani ja sympatiaa toista kohtaan.

Kysymys kuitenkin kuuluu, voisiko Bergsonin keston käsitteellä luonnehtia kokemusta toisesta henkilöstä juuri toisena, minusta erillisenä, sellaisella tavalla, joka eroaisi tilallisuuteen tai kehollisuuteen keskittyvistä analyyseista (vrt. esim. Husserl 1907; 1973; Merleau-Ponty 1945; Stein 2008 [1917]; Waldenfels 2009). Vastaavia kysymyksenasetteluja on vain jossain määrin havaittavissa klassisen fenomenologian empatia-analyyseissa, lähinnä Levinasilla (ks. Levinas 2012, 
I, 238-242, 286-298), vaikka Bergsonin ajattelulla onkin muuten ollut vaikutusta varsinkin ranskalaisten fenomenologien ajatteluun (ks. Landes 2012, xxxv; Lefort 1974, 694; Merleau-Ponty 1945, esim. 85, 313). Argumentoimme, että Bergsonin keston käsite avaa kokemusta toisesta ainutlaatuisella tavalla, joka jää saavuttamatta muissa toiseuden analyyseissa, mutta joka on kuitenkin tärkeä näkökulma toisen itsestä erillisyyden sekä yhteneväisyyden mahdollisuuksien ymmärtämiselle myös ylittäen kokemuksen nyt-hetken. Kokemusta toisesta henkilöstä juuri toisena henkilönä, minusta erillisenä olentona, jolla on oma kokemuksensa maailmasta, ei siis välttämättä tarvitse analysoida juuri vieraana (vrt. Waldenfels 2009), saavuttamattomana (vrt. Levinas 2012) tai ruumiillisista lähtökohdista käsin (vrt. Merleau-Ponty 1945; Stein 2008), vaan kokemusta toisesta voi analysoida myös ajallisena jatkumona. Emme tässä tee Bergson-eksegeesiä, vaan tutkimme Bergsonin ajattelun mahdollisia sovelluksia.

Bergsonin keston käsite yleisesti laajentaa ajallisuuden kokemuksen filosofista käsitteellistämistä. Bergson kritisoi vahvasti matemaattisluonnontieteellistä käsitystä ajasta, joka esittää ajan avaruudellisena ilmiönä, jota ihminen voi ajattelullaan hallita. Ajan tarkastelu keston käsitteen valossa esittää maailman todellisena ja kompleksisena, jossa aikaa ei voida pysäyttää. Näin ollen ajattelun täytyy tapahtua ajassa, jossa mikään asia ei tapahdu täysin samankaltaisena kahdesti, mutta mennyt on läsnä nykyisyydessä. Moyn (2005, 32-33) mukaan Bergsonin aikalaiset tulkitsivatkin Bergsonin kestollisen metafysiikan haastavan viime vuosisadan vaihteen kantilaisia sekä kartesiolaisia ajatuksia. Bergsonismi tarjosi uuden väylän tarkastella äärettömyyttä, jonka käsitteellistämisen suuri osa modernista filosofiasta oli hylännyt tarpeettomana tehtävänä.

Bergson-tutkimuksessa kokemus toisesta on jäänyt vähemmälle huomiolle. Kestosta ovat kirjoittaneet syvällisesti ja kattavasti tunnetuimpana esimerkiksi A.R. Lacey (1999), Heath Massey (2015), William Barnard (2011) ja Susanne Guerlac (2006). Myös sovelluksia Bergsonin työstä on monenlaisia, kuten kulttuurintutkimuksessa (Ardoin, Gontarski, Mattison, toim. 2013) ja postko- lonialistisessa tutkimuksessa (Pitts \& Westmoreland 2019). Kommentaarit tai sovellukset kuitenkin käsittelevät tietoisuuden ja kokemuksen muita alueita kuin toisen henkilön kokemista. Kokemus toisesta henkilöstä tematisoituu jossain määrin naurua ja komediaa käsittelevissä teksteissä, mutta sielläkin enimmäkseen implisiittisesti ja hajanaisesti (ks. esim. Hokenson 2013, Mullarkey 2013), sekä ihmisoikeusfilosofiassa moraalin ja rakkauden näkökulmasta (esim. Lefebvre 2017). Jälkimmäisessä bergsonilainen näkökulma on eksplisiittisempi ja selkeämpi, mutta se eroaa meidän analyysistamme siten, että näissä teksteissä toisia käsitellään normatiivisesti rakkauden ja sympatian kohteina, eikä kokemus toisesta ilman normatiivisia oletuksia toisiin kohdistuvista positiivisista tai negatiivisista tunteista tule esiin.

Bergsonilta selkeästi vaikutteita ottanut Levinas lähestyy toisen henkilön toiseutta ja sen äärettömyyttä keston käsitettä hyödyntäen, mutta samalla hän myös soveltaa ja muokkaa Bergsonin käsitteitä oman eettis-fenomenologisen ja teologisen tutkimuksensa työkaluiksi (Levinas 2012; 1998, 127-129; 1996a, 42-44; 1996b, 156-157, ks. Moyn 2005, 32-38). Levinas poimii Bergsonilta keston käsitteen analysoidessaan tietämisen rakentumista yhdessä muiden kanssa: tietämisessä olennaista ei ole ainoastaan, mitä tiedämme, vaan myös väylä, jonka kautta olemme tulleet tietämään jotain maailmasta. Keston kautta analysoituna tietoisuudesta ei eroteta tiettyä hetkeä tai kokemusta väylänä tietoisuuden käsitteistämiseen, vaan huomio kiinnittyy tietoisuuden mahdollistavaan ajallisuuteen (Levinas 1996a, 42-44). Bergsonin metodi ja näkemykset tietoisuudesta kuitenkin eroavat fenomenologian vastaavista näkemyksistä, vaikka Bergsonia joskus tutkitaankin varhaisten fenomenologien rinnalla (Kelly, 2010). Siksi on mielekästä ottaa uudestaan käsittelyyn kokemus toisesta Bergsonin keston käsitteen avulla ilman, että Bergsonia luetaan fenomenologina tai fenomenologisesta näkökulmasta.

Keston käsitettä on vaikea rajata mielekkäästi pois siihen liittyvistä muista ajallisuuden kokemuksen käsitteistä, kuten muistista tai elämän 
hyöystä (ks. esim. Lacey 1999, 13). Tämän takia olemme valinneet lähdekirjallisuudeksi erityisesti sellaisia Bergsonin teoksia, jotka käsittelevät ajallisuuteen liittyviä käsitteitä ja argumentteja: Essai sur le données immédiates de la conscience (1920a), L'énergie spirituelle: Essais et conferences (1920b) ja Matière et mémoire (2008 [1939]). Kokemus toisesta on limittynyt, ikään kuin piiloutunut näihin analyyseihin yhtäältä siksi, ettei kokemus toisesta ole Bergsonin analyysin päällimmäisiä aiheita ja toisaalta siksi, että ajallisuuteen liittyvät analyysit ovat koko Bergsonin tuotannon keskeisimpiä.

Bergson tekee eron juuri toisten ihmisten ja asioiden havainnoinnissa (Guerlac 2006, 43-44). Vaikka inhimillisen toisen havainnointiin liittyy omia erityispiirteitään, kokemus toisesta henkilöstä Bergsonin keston käsitteen avulla analysoituna merkitsee toiseuden tarkastelua laajemmin kuin pelkän inhimillisen toisen näkökulmasta. Tästä syystä emme rajaa kokemusta toisesta henkilöstä tiukasti pelkästään toisen ihmisen kokemukseen, mutta argumentin selkeyden vuoksi keskitymme inhimilliseen toiseen, toiseen henkilöön, joka on ihminen, eikä esimerkiksi jonkin muun lajin edustaja.

Käymme ensiksi läpi Bergsonin keston käsitteen ja sen, mitä keston käsitteen avulla voidaan sanoa toisen henkilön kokemuksesta. Tämän jälkeen esittelemme tarkemmin analyysia kokemuksesta toisesta minusta erillisenä sekä kokemustemme yhtenäisyydestä. Paneudumme elämän hyöyn käsitteen avulla siihen, miten Bergsonin filosofian pohjalta kokemus toisista henkilöistä on perustavampi kuin kokemus "minusta" muista erillisenä henkilönä. Lopuksi esittelemme toiseuden analyysin sovelluksia erilaisissa Bergsonin käsittelemissä ajallisuuden kokemuksissa: muistissa, luovassa toiminnassa ja toisen ennakoimattomuudessa sekä vapaudessa.

\section{Kesto: toisen ja minun}

Bergsonin keston käsite viittaa koettuun ajallisuuteen, jonkin asian rytmiin tai tapaan olla ajassa. Kesto konstituoituu avautuvasta tai paljastuvasta moninaisuudesta hetkissä, jotka seu- raavat toisiaan ikään kuin yhtenä ja erottamattomana jatkumona. Edelliset hetket vaikuttavat aina seuraavissa ja ovat niissä siinä mielessä läsnä. Toisiaan seuraavat elementit sulautuvat toisiinsa mutta ne ovat samalla myös loputtoman heterogeenisiä keskenään. Vaikka jokin hetki olisi joiltakin osin tismalleen samanlainen kuin jokin edellinen, kokemuksessa erona on aina se, että seuraavassa kokemuksessa on osana kokemus siitä, että on kokenut samanlaisen hetken kerran aikaisemminkin. (Bergson 1920a, luku 2; 1959; ks. myös Lawlor 2010). Sama toiminto tai havainto on erilainen ensimmäisen kerran kuin toistettuna tai totuttuna tavallisuutena. Tätä havainnollistaa hyvin Woody Allenin elokuvan Annie Hall (1977) kohtaus, jossa koomikko Alvy yrittää toisintaa aikaisempia hauskoja ja romanttisia kohtauksia Annien kanssa tuodakseen takaisin edelliset hauskat hetket. Menneiden hetkien toistaminen ei kuitenkaan onnistu, sillä nyt ne ovat jo menneeksi koetun toiston yrityksiä, sisältäen juuri kokemuksen tietoisesta toistamisesta, mikä tekeekin hetkistä ihan erilaisia ja Alvyn harmiksi vähemmän hassunromanttisia.

Bergsonille kaikilla koetuilla asioilla on kesto, oma rytminsä ja tapansa olla ajassa, joka paljastuu sen "toiminnassa" ja "tulemisessa" (Bergson 1907, 2). Tämä pätee niin elottomiin asioihin kuin elollisiin olentoihin. Erilaisten asioiden olemus paljastuu niiden kestossa ja niiden tullessa ajallisesti yhteen. Bergsonin usein käyttämässä esimerkissä sokeripalan (ks. esim. Bergson 1907, 10) olemus paljastuu sen sulaessa tai jähmettyessä sekä "minun" odottaessani kärsimättömästi sen sulamista. Yhteen tullessa minun oma kestoni sellaisena kuin sen koen toimii myös paljastajana muille kestoille, joiden rytmi on toinen esimerkiksi sokerin - ja jotka eroavat luontonsa puolesta omastani (Deleuze 2018, 27). Kuten Deleuze asiaa hahmottelee tilallisuutta vasten, kesto on aina luontoa koskevien erojen paikka ja ympäristö, jopa niiden kokonaisuus ja moneus; luontoa koskevia eroja on hänen mukaansa vain kestossa, kun taas tila on aste-erojen alue (mt., 28).

Myös toisella ja minulla on omat kestonsa. Kuten Eric Berlatsky Bergsonista inspiroituneena kirjoittaa, yhden henkilön nyt-hetki on toi- 
sen henkilön menneisyyttä tai tulevaa, jolloin voidaan myös ajatella, että kaikki ajat ovat samanaikaisia tai olemassa samaan aikaan (Berlatsky 2013, 261). Bergson ei ehkä vetäisi näin hurjia johtopäätöksiä kaiken samanaikaisuudesta, mutta Berlatskyn tekstissä näkyy hyvin ajatus siitä, ettei kaikkien henkilöiden koettu ajallisuus ole samanlaista. Kohdatessani toisen hänen olemuksensa paljastuu hänen kestossaan ja minun suhteessani häneen. Näin tulen tietoiseksi myös omasta kestostani. Saatan esimerkiksi olla väsynyt tai masentunut, kun toinen on virkeä ja havaitsee tilanteet ympärillämme tarkemmin ja nopeammin, mikä myös paljastaa minun ajallisen havaitsemisen ja kokemisen tapani. Saatamme myös tulla erilaisista ajankäytön kulttuureista, kuten stereotyyppisesti kiireisestä suurkaupungista ja hiljaiselta maaseudulta, jolloin tapamme käsitellä ympärillämme olevaa eroavat toisistaan ajallisesti. Toinen voi myös olla eri ikäinen, esimerkiksi minä voin olla keski-ikäinen ja toinen lapsi, jolloin kestomme ovat erilaisia, koska yhdellä on kertynyt muistia moninkertaisesti toiseen verrattuna ja samalla elämän odotukset ja asioiden merkitykset ovat erilaisia. Kesto paljastaa tässä juuri toiseuden, toisen erillisyyden itsestä ja minun kestoni juuri minuna, joka eroaa toisista. Liikkeemme eroavat toisistaan, katseemme kohdistuu vuoroin samaan, vuoroin eri pisteeseen, puheemme tai muut tekomme vuorottelevat toistensa kanssa ja paljastavat siten juuri toisensa. Analyysia voisi jatkaa toisen luonteenpiirteiden, mielialojen ja vaikka kulttuuritaustan paljastumiseen: oma rytmini voi olla yksityiskohdissaan erilainen kuin toisen rytmi.

Kesto on ajallinen käsite. Sen avulla voidaan avata toiseuden kokemuksen analyysia yli nyt-hetken. Toinen on kokemuksessani tässä ja nyt, mutta nyt-hetki rakentuu muistoille, tottumuksille, aikaisemmille kokemuksille ja tuleville odotuksille. Bergsonille ihmiskokemus on ajallista ja jatkuvaa. Jokainen hetki näyttäytyy ja saa merkityksensä yhdessä edellisten hetkien kanssa (Bergson 1920a, 75-80; 1907, 2-12). Emme ole olemassa vain staattisesti, vaan inhimillinen olemassaolo on jatkuvaa tulemista - kestoa - ja historiallista siinä mielessä, että maailma näyt- täytyy menneen muovaamana ja juuri mennyttä vasten uutena. Jokainen elämä on Bergsonille uniikki juuri historiallisuudessaan: kaikki, mitä on ollut, on mukana jokaisessa kokemuksessa maailmasta, toisista ja itsestä (Bergson 1920a, 143-47). Näin toisessa henkilössä ovat implisiittisesti mukana hänen koko historiansa, aikaisemmat ja kenties odotettavissa olevat kohtaamiset toisten ihmisten kanssa. Samoin minun aikaisemmat kokemukseni ovat mukana siinä, miten toiset henkilöt näyttäytyvät minulle kokemuksessani, ja toisen henkilön kokeminen taas osaltaan muokkaa minun seuraavaa kokemustani. Siinä, missä toiseuden kokemusta on usein 1900-luvun filosofiassa käsitelty kehollisuuden kautta, Bergson lähestyy, joskin lyhyesti, toiseutta toisena elämänmittaisena jatkumona (Bergson, 1920a, 140-47). Toisen henkilön omassa kokemuksessa ovat samoin mukana kaikki hänen siihen mennessä elämänsä hetket, jotka tekevät tämän henkilön kokemuksista juuri niitä kyseisiä kokemuksia. Oma ja toisen elämä ovat molemmat elämänmittaisia historiallisia jatkumoita, ja toisen kokemus on sellaisenaan saavuttamaton juuri siksi, että kukaan ei voi elää toisen elämää ja siten kokea toisen kokemuksia juuri sellaisena kuin toinen kokee ne osana oman elämänsä jatkumoa (Bergson 1920a, 143-47).

Keston käsitteen avulla voidaan ajatella kokemusta toisesta jossain mielessä jatkuvana myös sen jälkeen, kun kommunikointi toisen kanssa on ohi, kun toinen ei enää ole edessäni tai kun toinen koetaan olemassa olevana jossakin muualla, esimerkiksi ennen tapaamista tai ikävöidessäni kaukana olevaa toista. Kesto viittaa elettyyn aikaan, ei niihin matemaattisesti mitattavissa oleviin ajan määreisiin, joilla voidaan asettaa aika tarkkoihin yksikköihin. Kesto on sitä jakamatonta, tavallaan loputonta kokemuksen jatkumoa, joka on annettu intuitiivisesti (välittömästi ja konkreettisesti) (Lawlor 2010). Kuten monet tietoisuusfilosofit, esimerkiksi fenomenologit Husserlista nykypäivään, myös Bergson havainnollistaa ajallisuuden analyysiaan musiikin avulla. Muodostaessaan melodian sävelet eivät ole olemassa itsenäisinä yksiköinä, vaan osana kokonaisuutta, jossa ne ovat olemassa vain suhteessa 
toisiinsa. Yksittäiset sävelet ikään kuin sulautuvat ja punoutuvat sisäkkäisiksi (Bergson 1920a, 75-76). Samalla tavalla kokemus toisesta henkilöstä voidaan nähdä ikään kuin melodiana, joka ei tule tyhjästä tai koostu toisistaan irrallisista hetkistä ja jonka vaikutus pysyy toisen lähdettyä.

Näin myös kokemus toisesta henkilöstä on osa kokemusten jatkumoa, eikä kokemus katkea huomion kiinnittyessä johonkin muuhun. Bergson kritisoi ajan hahmottamista tilallisen metaforan kautta ikään kuin janana, joka voidaan jakaa osiin. Melodiaesimerkissä sävelet kirjoitetaan paperille erillisinä nuotteina nuottiviivastolle, mutta tämä on vain suuntaa-antava ohje, joka ei tavoita todellista melodian kokemusta (Bergson 1920a, 75-78). Tässä tulee esille myös Bergsonin filosofialle keskeinen ajan ja tilan havaitsemisen tapojen ero: tilalliset asiat, kuten esineet tai viivat paperilla, voidaan erotella toisistaan, mutta ajallisuutta ei voida erotella samalla tavalla, vaan ajallisuus on yhtä virtaavaa jatkumoa (mt.). Musiikkikappaleella on siis määrätty kesto ja sen havaitseminen vaatii kuulijalta kykyä tukeutua menneeseen ja nojautua tulevaan. Musiikki rakentuu kokonaisuudeksi, kun sävelet virtaavat yhtäjaksoisesti hetkestä toiseen ja kun soittajat sekä kuulijat tulkitsevat sävelten virtauksen kokonaisuudeksi. Esitetty teos on ajallisesti ainutkertainen, ja vaikka se toistettaisiin esimerkiksi korvakuulokkeissa uudelleen täysin samana, kuulija ymmärtää kuulevansa saman esityksen toistamiseen. Toistettu kappale rakentuu ensimmäisen kuulokokemuksen varaan, ei siitä erillisenä.

Bergsonin mukaan koettu aika ei ole määrällistä, kvantitatiivista, vaan laadullista, kvalitatiivista. Kesto voi olla enemmän tai vähemmän intensiivistä, mutta jakamatonta, ja siten se on täysin erilaista kuin tilallisuus (Bergson 1920a, luku 2). Esimerkiksi minuutti ajan määreenä on aina yhtä pitkä, mutta koettu aika, johon keston käsite viittaa, ei kerro, onko kulunut minuutti vai tunti. Bussin odottaminen muutamia minuutteja voi olla tuskallisen hidasta, kun taas juhlissa saattaa vierähtää huomaamatta useita tunteja. Elettyä aikaa ei siis koeta määränä, "pitkänä" tai "lyhyenä" samassa mielessä kuin tilalliset oliot, vaan enemmän tai vähemmän intensiivisenä, hitaana, tylsänä tai nopeana. Kokemus ei lakkaa tai vaihdu osasta toiseen sen jälkeen, kun jokin hetki on kulunut, vaan jatkuu, vaikka kokijan tuntemukset, paikat tai suhteet ympäristöön vaihtuvat. Näin toisen henkilön kanssa vietetyn hetken jälkeen yksinäiset hetket näyttäytyvät juuri toisen kanssa vietetyn ajan jälkeisinä. Toinen henkilö ei katoa tietoisuudesta vaan hän on myös poissaolevana mukana muokkaamassa kohtaamisen jälkeisiä hetkiä. Tätä voisi jossain määrin verrata Husserlin (1954) näkemyksiin maailman kokemuksesta intersubjektiivisena, toistenkin tietoisuuksien havaitsemana. Husserlille kuitenkin koettua maailmaa konstituoiva intersubjektiivisuus on anonyymia eli potentiaalisia toisia, ei juuri tiettyjä. Toki sekä Husserl (1973) että Stein (1917) analysoivat myös muistamista ja muistoa toisesta henkilöstä, mutta he tekevät sen rajaamalla tutkimuskohteekseen vain yhden kokemuksen, ottamatta huomioon kokemusten jatkumoa kestona. Husserl myös kirjoittaa tietoisten prosessien virrasta, mutta tämä ei tarkoita kokemusten jatkumoa bergsonilaisessa mielessä (ks. esim. Husserl 1976, \$33).

Bergson vertaa keston intensiteettieroja tunteisiin: tyytyväisyyden ja onnen laatu on täysin erilainen, eikä onnellisuuden voida sanoa olevan ikään kuin ylemmän tason tyytyväisyyttä tai määrällisesti enemmän tyytyväisyyttä (Bergson 1920a, 93). Kesto ei siis ole laadullisesti jatkuvasti yhtä ja samaa, vaan hetket, vaikkakin osana yhtä loputtomalta näyttävää jatkumoa, ovat keskenään laadullisesti erilaisia eli heterogeenisiä (ks. Bergson 1959). Kokemukset toisen läsnäolosta ovat keskenään erilaisia, mutta toinen ei ole kokemuksessa jotenkin enemmän tai vähemmän, vaan eri tavoin eri hetkinä. Samoin kokemukset toisesta ja kokemukset, joihin toinen ei liity, eivät ole määrällisesti, vaan laadullisesti erilaisia. Tässä tuleekin huomata, että eletyssä kokemuksessa ei ole olemassa ns. "puhdasta" kestoa, vaan kokemus koostuu aina monesta elementistä, Bergsonille kestosta ja tilasta, kehollisuudesta ja kaikista edellisistä kokemuksista. Kesto on samaan aikaan yksi kokemuksen ehdoista ja sen piirteistä sekoittuneena muihin kokemuksen piirteisiin 
(ks. Bergson 1920a, 100; 1972, 354; ks. myös Lacey 1999,34$)$. Toisin sanoen kokemuksen itsensä ehto näkyy kaikessa kokemuksessa, mutta ei koskaan puhtaana, sillä kokeaksemme maailmaa meidän tulee myös olla tilassa, suhteessa ympäristöön, tuntevia, kehollisia ja niin edelleen.

\section{Toisen erillisyys ja yhteneväisyys}

Kun kumpikin on elollinen olento tai ihminen, toisen ja minun kestot ovat lähempänä toisiaan kuin esimerkiksi ihmisen ja sokeripalan tapauksessa. Toiseuden ajatteleminen keston kautta antaa tilaa yhteneväisyyden analyysille toisin kuin ajatellessa toiseutta tilallisuuden avulla. Siinä missä toinen on tilallisesti fyysisenä kehona aina tietyssä uniikissa tilallisessa pisteessä erotettuna toisista kehoista toisissa uniikeissa paikoissa, vaikka kuinka lähellä toista tahansa, voi toiseen ja toisen rytmiin yhtyä ajallisesti. Siinä missä tila on Bergsonille ulkoista, kestoa ei voida määrittää sisäiseksi tai ulkoiseksi (Bergson 2008, 27; ks. myös Lacey 1999, 33). On mahdollista tulla yhteen ja kokea jaettu, yhteinen kesto yhteisessä tekemisessä, kuten kuorolaulussa, jossa oma ääni sulautuu täysin muiden ääneen. Kehoillamme tuotetut sävelet punoutuvat yhdeksi melodiaksi, ja olemme tekemässä samaa tilannetta yhdessä, yhdistyen toistemme ääniin. Muita esimerkkejä ovat kokemus yleisössä olemisesta, jossa toisten katsojien erillisyys itsestä unohtuu ja kokemuksen rytmi on ainakin hetkittäin yhteinen tai vaikka kokemus live-pelaamisesta toisten kanssa verkossa niin, että oma toiminta sulautuu toisten toimintaan yhteisessä päämäärässä ja kokemus itsen erillisyydestä toisista hämärtyy tai katoaa hetkittäin. Näin eri henkilöiden kestot ikään kuin sulautuvat yhteen ja erottautuvat jälleen tilanteen mukaan.

Bergsonin mukaan tilalliset kappaleet voidaan erottaa toisistaan, kun taas ajassa ei ole tällaisia toisistaan eroteltavissa olevia kappaleita, ainakaan muuten kuin metaforisesti (Bergson 1920a, luku 2). Bergson käyttää tässäkin yhteydessä esimerkkinä melodiaa: jos kaksi säveltä erotetaan toisistaan, niiden väliin jää intervalli, hiljaisia hetkiä, ja ne ovat edelleen suhteessa toisiinsa yhtenä jatkumona, vaikkakin toisenlaisena kuin jos ne olisi sidottu yhteen yhdeksi melodiaksi (mt.). Jos jokin siis jäisi keston ulkopuolelle, se ei olisi osa kokemusta lainkaan, sitä ei ikään kuin olisi. Jos jokin taas on tilallisesti ulkoista, se on edelleen olemassa suhteessa täällä-pisteeseen.

Tästä syystä tietoisuudessa ei ole olemassa sisäistä ja ulkoista (Bergson 1920a, luku 2). Toinen henkilö ei ole kokemukseni ulkopuolella, vaikka toisen kokemus ei ole minun kokemukseni eikä toisen keho ole minun kehoni. Toinen on silti minun kokemuksessani, osa minun kokemustani. Bergsonin ajattelun pohjalta toista ja toiseutta ei siis ole mielekästä ajatella ainoastaan ikään kuin ulkopuolisena tilallisin metaforin, vaikka kehot ovatkin koettuja sekä tilassa että kestossa. Kesto siis rikkoo puhtaan tilallisuuden kokemuksen toisistaan erillisinä kappaleina ja tuo ne yhteen. Vaikka kesto paljastaa toisen toiseuden, se myös saattaa häivyttää sen.

Bergsonin keston analyysien perusteella voidaan argumentoida, ettei toiseuden kokemuksen keskiössä ole ensisijaisesti esimerkiksi toisen elävän kehon havainto, kuten fenomenologien argumenteista voisi päätellä (esim. Husserl 1954; Merleau-Ponty 1945; Stein 2008), vaan toisen toiminta, joka havaitaan ajallisena, yhteensulautuvina hetkinä. Toki myös fenomenologit, kuten Husserl, ovat argumentoineet toiseuden näkyvän kehon ja ilmaisun spontaanissa liikkeessä ja siten ajallisessa kokemuksessa (Husserl 1954; 1973). Bergsonilaisittain voidaan kritisoida toiseuden havainnon analyysin tilallisia metaforia, joista keskeisimpinä on näkökulma: minun ruumiini on aina "tässä", ja toisen on aina "tuolla", toisessa tilallisessa paikassa, vaikka kuinka lähellä minua. Toinen ei siis koskaan voi kokea maailmaa samasta paikasta samaan aikaan kuin minä (Husserl 1907). Bergsonilaisittain toisen kokemus juuri sellaisena kuin toinen sen kokee ei ole saavuttamaton minulle siksi, etten "minä" voisi koskaan kokea toisen näkökulmaa niin kuin hän sen kokee, vaan koska en voi omata toisen elämän historiallista jatkumoa.

Voidaan myös argumentoida, ettei analyysin tarvitse rajoittua vain jompaankumpaan tekijään, ajallisuuteen tai tilallisuuteen. Bergsonille kokemus on aina koosteita, ei koskaan puhdasta 
kestoa tai ulottuvaisuutta, vaan molempia, yhdessä muiden kokemuksen konstitutiivisten ainesten kanssa (Deleuze 2018, 21; ks. Bergson 1920a, $100 ; 1972,354 ; 1907)$. Toisen ajallinen ja historiallinen kokemus näkyy juuri toisen toiminnassa, joka taas näkyy joko toisen kehollisessa tai muussa materiaalisesti välittyneessä ilmaisussa. Kesto paljastuu tilassa. Bergsonin keskeinen ajatus on kuitenkin se, ettei analyysin tulisi sekoittaa näitä kahta asiaa toisiinsa, vaan ymmärtää keston ja tilan olemukselliset erot ja siten niiden roolit kokemuksen, myös toiseuden kokemuksen, muodostumisessa (Bergson 1920a).

\section{Elämän hyöky: yhteisestä yksilöön}

Bergsonin keston käsite liittyy olennaisesti ajatukseen ajasta virtauksena ja katkeamattomana kokemuksena. Kesto on osa inhimillistä kokemusta, eikä Bergson anna maailmalle selkeästi omaa kestoa (ks. Lacey 1999, II, 4, 8). Maailman virtauksessa ihmisen persoonallinen kesto on toiminnallista yhtenäisyyttä, jossa kaikki edeltävät kokemukset virtaavat nykyhetkessä kohti tulevaa. Maailmankaikkeuden liikkeessä persoonallinen kesto on keholliseen toimintakeskukseen sidottua ja keston omaava keho vie toiminnallaan eteenpäin elämän voimaa. Maailman ajallisuuden käsitteellistämiseen Bergson hyödyntää toista kestolle osittain rinnakkaista käsitettä, élan vital, elämän hyöky, kuten Juho Hollo termin onnistuneesti kääntää (Bergson 1958). Lacey (1999) tulkitsee elämän hyöyn analyysin Bergsonin omaksi evoluutioteoriaksi, jossa inhimillinen elämä ja tietoisuus irtaantuvat persoonalliseksi kestoksi maailman elämän hyökymisestä. Elämän hyöyn käsite kuvaa, kuinka elämä virtaa materiaa muovaavana ja taivuttavana voimana.

Koska kestoa ei voida mallintaa matemaattisesti tilalliseen abstraktioon, Bergson rakentaa keston analyysiin intuitioon perustuvaa metodia, jonka rakenne yksinkertaisimmillaan pohjautuu kahden näkökulman erottamiseen toisistaan:

[Ensimmäinen] on tavanomainen tai hyödyllinen tieto ja toinen puhdas tieto. Kesto, jossa näemme itsemme toimimassa ja jossa meidän on hyödyllistä nähdä itsemme toimimassa, on kesto, jonka elementit eroavat ja asettuvat vastakkain. Kesto, jossa me toimimme on kestoa, jossa tilamme sulautuvat yhteen. (Bergson 2008 [1939], 224, suom. KC)

Bergson siis erottaa toisistaan keston, jossa näemme itsemme toimimassa kestosta, jossa me toimimme. Ensimmäisessä kestossa havaintomme rajoittuu tarkastelemaan keston elementtejä toisistaan erillisinä ja vastakkaisina. Toisessa keston näkökulmassa tilamme sulautuvat yhteen, ja voimme havaita olevamme osa maailman liikettä ja elämän hyökyä.

Elämän hyöyn käsitteen kautta ajateltuna olemme lähtökohtaisesti osana maailman liikettä, jolloin myös toisen henkilön kokemus on annettu ja itsestäänselvyys, ennen kyseisen kokemuksen teoretisointia. Toisin kuin monet empatiateoreetikot, Bergson ei etene ajattelussaan itsestä kohti toisia vaan yhteisestä yksilölliseen. Hän kritisoi tapaa tutkia itsen ja toisen suhdetta lähtien yksilöstä, sillä todellisuudessa ihminen kehittyy ja kasvaa juuri yhteisestä kohti yksilöllistä (Bergson 2008, 46-48). Moni filosofi on kuitenkin käsitellyt itsen ja toisen suhdetta juuri päinvastoin: olettamalla olevansa ensin valmis yksilö maailmassa ja vasta sen pohjalta rakentavansa suhdetta muihin (ks. Lipps 1883, 1898, Husserl 1973, Stein 1917).

Bergsonille olemme ensin osa elämän hyökyä ja vasta sen kautta tulemme tietoisiksi itsestämme, ei toisin päin. Bergsonin mukaan elämän yleinen voima tai henki muokkaa materiaa, josta inhimillinen elämä erottautuu itsenäiseksi toimintakeskukseksi. Inhimillinen elämä on siis Bergsonin mukaan ensin yhteistä ja jaettua, ja vasta toiseksi yksilöllistä ja omaa. Vauva on tietämätön oman kehonsa ja tajuntansa rajoista, mutta oppii antamaan omalle keholleen etuoikeutetun paikan. Elämän kokemuksen kautta yksilö siis alkaa suhteuttaa omaa kestoaan muihin ja siten erkanee suuresta joukosta omaksi toimintakeskukseksi. (Bergson 2008, 45-47.) Bergsonin pohjalta voidaankin todeta, että ajattelun aloittaminen keskuksesta kohti periferiaa ei tee oikeutta ihmiselämän kestolliselle laadulle: "Näin aine erottelee ja erottaa yksilöiksi ja lopulta per- 
soonallisuuksiksi taipumuksia, jotka ennen sekoittuivat elämän alkuperäiseen hyökyyn"(Bergson 1920b, 29, suom. KC) Bergsonille ihmisen yksilöllinen kesto on erottautumista itsenäiseksi toimintakeskukseksi siitä elämän virtauksesta, jossa maailman dynaaminen elämän hyöky luo jatkuvasti uutta.

Sellaista ajattelua, jossa toiset henkilöt ovat lähtökohtaisesti osa omaa maailmassa olemista löytyy omilla tavoillaan myös fenomenologeilta, esimerkiksi Heideggerilta ja Levinasilta. Heideggerille maailmassa oleminen on lähtökohtaisesti kanssaoloa (Mitsein). Inhimillinen henkilö on hänelle "täällä" olevaa, elävää ja kokevaa, "täälläolo" (Dasein), jonka olennaista suhdetta toisiin Heidegger avaa käyttämällä täälläolosta myös termiä "kanssa-täälläolo" (Mitdasein) (ks. Heidegger 2006, \$26). Levinas ottaa toisen lähtökohtana itsen kokemukselle maailmasta ja itsestä. Analyysissään hän hyödyntää lyhyesti juuri Bergsonin elämän hyöyn käsitettä ja ottaa sen avulla kantaa myös Heideggerin aikaisempiin tutkimuksiin. (ks. Levinas 2012, 238-242.)

\section{Ajallinen kokemus toisesta erilaisissa käytännöissä}

Kokemus toisesta henkilöstä limittyy monenlaisiin keston konstituoimiin ilmiöihin. Seuraavissa osioissa analysoimme tätä kokemusta kolmen Bergsonin ajallisuuden kokemukseen liittyvän ilmiön kautta, jotka ovat muisti, luova toimita sekä toisen vapaus ja ennakoimattomuus. Muisti on Bergsonille inhimillisen elämän keskeisiä piirteitä, joka mahdollistaa inhimillisen kokemuksen. Luova toiminta taas on keskeinen osa inhimillistä maailmassa toimimista. Toisen vapaus ja ennakoimattomuus taas on yksittäinen, tietynlainen kokemus, joka on myös yksi Bergsonin syvimmin analysoimista kokemuksista toisesta henkilöstä ja jossa tulevat yhteen ajallisuuden eri ilmenemismuodot inhimillisessä kokemuksessa. Näin toisen ennakoimattomuuden ja vapauden analyysi vetää yhteen tässä artikkelissa esiteltyjä aiheita: kestoa, kokemusta toisesta, elämän hyökyä, muistia ja luovaa toimintaa, joista mikään ei inhimillisessä kokemuksessa ole "puhtaana", vaan aina yhdessä tilallisuuden ja kehollisuuden kanssa.

\section{Muisti}

Erillisten toimintakeskusten - minun ja muiden - sulautuminen ja erkaantuminen toisistaan tulee mahdolliseksi muistamisen kautta. Bergsonin mukaan kokemukset toisista toimintakeskuksista tukevat yksilön tietoista erottautumista maailmasta omaksi elämän keskukseksi. Kehomme saa etuoikeutetun aseman suhteessa muihin toimintakeskuksiin vain kokemuksen ja siitä jäävien muistikuvien myötä. Näin toinen henkilö koetaan itsestä erillisenä toiminnan keskuksena. Lapsi oppii tunnistamaan oman kehonsa rajat ajallisesti ja havaitessaan oman toimintansa erillisyyden muusta maailmasta. Tullakseen tietoiseksi oman kehonsa erillisyydestä ja yksilöllisen toimintansa mahdollisuuksista lapsen täytyy harjaannuttaa kehonsa tuntemuksia sekä mielikuvien tulkintaa. Pikkuhiljaa kehosta tulee yksilön olemuksellinen representaatio, jonka kautta kaikki muut havaittavat kuvat ja tuntemukset kulkevat tietoisuuteemme. (Bergson 2008, 45-47.)

Kesto jatkumona liittyy olennaisesti myös muistiin. Bergsonille kesto on jatkuvaa elävää muistia, joka ulottaa menneen nykyisyyteen lyhyemmältä ja pidemmältä ajalta (Bergson, 1959, 141). Ilman tätä ei olisi kestoa, olisi vain nykyisyyttä. Mikään asia ei olisi mitään, koska mikään ei liittyisi mihinkään tai merkitsisi mitään. Ilman muistia jokainen hetki olisi kokemuksena irrallaan menneestä, jolloin hetkien merkityskin olisi toinen. Juuri muistin ansiosta nykyhetket näyttäytyvät erilaisina menneestä, eivätkä samanlaisina kuin edelliset hetket, ja ovat mukana nykyisyyden konstituutiossa (Lawlor, 2010). Kuten Lawlor asian ilmaisee, sunnuntai, maanantai ja tiistai ovat erilaisia päiviä, koska maanantain kokemus sisältää sunnuntain ja tiistain kokemus sisältää sekä maanantain että sunnuntain (Lawlor, 2010). Juuri muistin ansiosta inhimillisen elämän kesto on niin pitkäkestoista kuin se on.

Bergsonin mukaan muisti sovittaa tilassa tehtävän havainnon sekä sen laadullisesti havaittavan keston. Eletyssä kokemuksessa havainto ja 
muisti läpäisevät aina toisensa. Muistelussa ihminen asettaa virtuaalisesti itsensä muistikuvaan ikään kuin kyseessä olisi havainto. Muistamisessa ihmisen mieli ja maailman materiaalisuus yhdistyvät. (Bergson 2008, 153-156.) Kuten Deleuze on Begsonia soveltaen argumentoinut, muisti liittää koetut hetket toisiinsa ja ikään kuin sujauttaa menneisyyden nykyhetken sisään. Muisti saa aikaan sen, että keho ei ole vain hetkellinen ja antaa sille keston ajassa (Deleuze, 2018).

Bergsonin mukaan muisti ja ajallisen kokemuksen historiallisuus myös erottavat meitä toisistamme. Nykyhetken kokemus perustuu menneisiin kokemuksiin, jotka tekevät nykyhetkestä tietynlaisen (1920a, luku 2). Näin kahden henkilön kokemukset eroavat laadullisesti toisistaan, vaikka he olisivatkin läheisiä. Vaikka kestomme voivat yhtyä joskus, itse kokemus saattaa olla eri henkilöille erilainen. Esimerkiksi toisiin sulautuva kuorolaulu saattaa yhdelle olla jotakin uutta, toiselle kappale muistuttaa menneistä hyvistä hetkistä ja kolmas voi olla kokenut kuorolaulaja, jolle kyseinen kappale ei kuitenkaan merkitse mitään. Näin henkilöiden rytmit ovat yhdessä, eikä tois(t)en erillisyys itsestä tai itsen erillisyys toisesta tai toisista välttämättä tule esiin, mutta kaikkien kokemus on kuitenkin historiallisuudessaan uniikki.

Muistot aktualisoituvat toimintana. Bergsonin mukaan ihminen eriytyy elämänsä toimintakeskukseksi, jolla on oma kesto. Omasta kehosta tulee minuuden muuttumaton viittauspiste, johon tilassa liikkuvat havainnot peilautuvat. Toisin sanoen siinä missä yksilön havainnoissa maailma ympärillä toisinaan liittyy yksilöön ja erkaantuu tästä, yksilö on kiinnittynyt omaan toimintakeskukseensa. Tässä prosessissa juuri ihmisen muisti punoo yhteen menneisyyden ja nykyisyyden liikkeen yhtenäiseksi virtauksen kokemukseksi. (Bergson 2008, 153-156.) Bergsonin mukaan kestosta on siis havaittavissa kahdesta osasta rakentuva tiheys:

Itse asiassa me havaitsemme keston tiheyden, joka rakentuu kahdesta osasta: meidän lähimenneestämme ja lähestyvästä tulevasta. Menneeseen me tukeu- dumme ja tulevaan nojaudumme; tukeutuminen ja nojautuminen ovat siis tietoisen olennon ominaisuuksia. (Bergson 1920b, 6, suom. KC, vrt. Bergson $1958,9$.

Tietoinen olento lukee maailmaa tukeutuen lähimenneeseen ja samalla nojautuen tulevaan. Tukeutuminen tapahtuu muistikuvien ja havainnoinnin yhtäaikaisuutena, mikä liittää toisiinsa virtuaalisen ja reaalisen maailman. Muistikuva lähimenneestä tiivistyy koettuun hetkeen ja virtaa sulavasti kohti tulevaa. Näin mieleen painunut muistikuva kykenee sovittamaan tietoisen olennon tilassa tapahtuvaa toimintaa suhteessa sen kestolliseen laatuun (ks. Deleuze 2018).

Kokemuksessa toisesta henkilöstä itsestä erillisenä toisena toinen on oma toimintakeskuksensa ja minä omani, vaikka me tekisimmekin jotakin yhdessä. Bergsonilaisittain ajateltuna tämä mahdollistuu muistin ansiosta. Toinen koetaan tuttuna tai vieraana, tulossa jostakin ja menossa jonnekin, niin metaforisesti kuin kirjaimellisesti juuri sen ansiosta, että voin muistaa vähän tai kauan aikaa sitten havaittua.

\section{Luova toiminta}

Bergsonilainen kesto kokemuksessa toisesta henkilöstä ilmenee myös haasteena luovaan prosessiin, jossa ei ole kyse jo olemassa olevien asiantilojen vahvistamisesta, vaan toisen keston kokemuksellisesta painosta, joka muokkaa yksilön kestoa. Toisen seuraaminen ja eräänlainen "mallintaminen" eivät koskaan ole täydellisiä, koska toisen kesto ei ole matemaattinen malli vaan luovaa ajattelua, johon minun ruumiini mukautuu kun seuraan toista. Bergson viittaa muun muassa vieraan kielen puhujien havainnointiin (Bergson 2008, 120-128), lapsen tapaan oppia havainnoimaan ja painamaan mieleensä lelukaupan ikkunassa näkemiään esineitä (Bergson 1958, 153) ja shakkipelaajien tapaan toisintaa shakkipelejä virtuaalisesti mielessään (Bergson 1958, 153). Kaikissa näissä esimerkeissä on näkemyksemme mukaan kyse juuri kokemuksesta toisesta henkilöstä ja tämän kokemuksen linkittymisestä Bergsonin 
keston käsitteeseen.

Bergsonille ainetta muovaava elämän virtaus tiivistyy ihmisen uutta luovaan toimintaan. Ihmisyyden erityisyys onkin Bergsonin mukaan nähtävillä juuri luovassa työssä, jossa ihminen taivuttaa ainetta oman ajattelunsa jatkeeksi:

Jos siis kaikilla alueilla elämän voitto on luominen, eikö meidän pitäisi olettaa ihmiselämän olemisen tarkoitukseksi uuden luominen, joka on joka hetki läsnä jokaisessa ihmisessä: itsensä luominen itsensä kautta, oman persoonallisuuden suurentaminen ottamalla paljon vähästä, ottamalla jotain olemattomasta ja siten lisäämällä lakkaamatta rikkautta maailmaan? (Bergson, 1920b, 31, suom. KC.)

Inhimillisen elämän rajat piirtyvät ajassa ihmisen luovan toiminnan seurauksena, minkä vuoksi juuri uuden luominen on läsnä ihmisen kestossa. Bergson siis lähestyy ihmisen luovaa toimintaa hyvin laajassa mielessä. Luovuus ei rajoitu vain taiteellisuuteen tai filosofin ajattelutyöhön, vaan inhimillinen toiminta muokkaa materiaa luovasti myös silloin kuin elämän hyöky näennäisesti vain virtaa ihmisen lävitse toistaen jo rutiiniksi muodostuneita toimintamalleja.

Kuvaamassaan älyllisessä toiminnassa Bergson (1958) erottelee toisistaan mieleen palauttamisen ja keksivän älyllisen toiminnan. Analysoidessaan keksivää älyllistä toimintaa Bergson näyttää viittaavan toisen ihmisen havainnointiin, mikä puskee älyllistä toimintaa omaksumaan itselleen vieraita toimintamalleja. Hänelle jokainen henkilö tai persoonallisuus on luova voima, joka on mukana siinä, mitä havaitsemme (Mélanges, 1071; ks. Antliff 2013, 299). Siinä missä mieleen palauttaminen vaikuttaa virtaavan helpommin ajatuksien tasojen halki, keksivä älyllinen ponnistelu vaatii niin ajattelun kuin kehon taivuttamista uusiin muotoihin. (Bergson 1958, 149-151.) Molemmissa prosesseissa on osittain läsnä muistikuvien "mekaaninen palautuminen ja osittain älyllinen uudelleensommittelu". (Bergson 1958,152 .) Toisen aiheuttamasta haasteesta Bergson nostaa esimerkkinä valssin oppimisen, jossa valssin oppija huomioi toisen tanssivan valssia ja pyrkii mallintamaan omassa kehos- saan näkemänsä askeleet ja liikkeet. Valssin oppimiseen ei lähtökohtaisesti tarjota matemaattista mallia vaan tanssi opitaan toisen luovan toiminnan seuraamisesta ja sen mukauttamisesta omaan kehoon. (Bergson 1958, 174, vrt. Bergson 2008, 120-128). Toisen toiminnan havainnointi rikkoutuu kehossa erillisiin osiin, joiden virtausta toisintamalla liike löytää soljuvan kanavansa kehollisena toimintana. Toisen mallintama liike jää keholliseen toimintakeskukseen muistikuvana, jonka haltuun ottaminen vaatii muistikuvan rikkomista ja uudelleenmuokkausta. Liikkeen kehollista analyysia jatkaessaan toisen toiminnasta muodostettu muistikuva ohjaa yksilöä kohti luonnolliselta tuntuvaa liikettä. (Bergson 2008, 120-128.) Lopulta valssin askeleet opittuaan tanssija voi kokea liikkeen virtaavan luonnollisena osana olemustaan. Liike palautuu mieleen ja kehoon virtauksena, jota ei tarvitse tietoisesti hakea ajatuksen tasoista.

\section{Toisen vapaus ja ennakoimattomuus}

Kokemus toisesta liittyy Bergsonilla vahvasti myös vapauteen. Koska oma muisti ja kesto ovat erillisiä toisen muistista ja kestosta, toinen henkilö ei ole ennakoitavissa tai ennustettavissa, eikä siten hallittavissa. Bergson vertaa tilannetta luonnontieteeseen, jonka tarkoituksena on ennustaa: ennustaminen on hänen mukaansa oikeastaan olettamista menneen perusteella. Toisen elämän koko menneisyyttä ja nykyisyyttä yhtenä elämän jatkumona ei kuitenkaan voi kokea kukaan muu, eikä toisen tulevaisuutta, edes lähitulevaisuutta, voida siten ennustaa tai varsinkaan hallita. (Bergson, 1920a, luku 2.) Kuten Husserl myöhemmin argumentoi toiseudesta, myös Bergson esittää, että jos joku kokisi toisen kokemukset niin kuin se toinen, kyseessä ei olisi toinen henkilö, vaan yksi ja sama henkilö (ks. Bergson 1920a, 143; Husserl, 1973). Edes koko elämänsä yhdessä eläneiden identtisten kaksosten kohdalla ei voitaisi puhua toisen toiminnan todellisesta ennustamisesta tai hallitsemisesta, sillä kumpikaan ei ole elänyt toistensa kokemuksia niin kuin toinen kaksonen ne on kokenut. 
"Tuleminen" ja kesto koko inhimillisen elämän olennaisena tekijänä liittyvät myös siihen, miten Bergson näkee toiseuden ja mitä toiseudesta voidaan hänen argumenttiensa perusteella päätellä. Koska kaikki menneet kokemukset muokkaavat nykykokemusta, kenelläkään toisella ei voi olla täysin samaa kokemusta, vaikka yhteisiä kokemuksia voi toki ollakin. Eri henkilöillä on siis yhdessäkin vietetystä nykyhetkestä erilliset kokemukset, ei vain sen takia, että "minä" en ole "sinä", vaan siksi, että kyseessä on kaksi erillistä elämän jatkumoa. Jokaisen kokemus yhdessä vietetystä hetkestä on siis ainakin jossain määrin erilainen siinä mielessä, että koettu hetki on jatkoa kaikelle edelliselle ja jokaisen elämä on ainakin jossain määrin erilaista. Näin esimerkiksi yhdessä koetuista asioista keskusteleminen on mielekästä tai pitkään toisensa tunteneet henkilöt voivat vuosienkin päästä oppia toisistaan jotakin uutta.

Toisen ennakoimattomuus myös askarruttaa älyämme:

Palauttaessamme mieleemme menneitä asioita, selittäessämme nykyisyydessä ilmeneviä tosiasioita, kuunnellessamme esitelmää, seuratessamme toisten ajatuksia ja kuunnellessamme omia mietteitämme, sanalla sanoen: monipuolisen havainto- tai mielikuvajärjestelmän askarruttaessa älyämme, me tunnemme voivamme paneutua kahteen erilaiseen asenteeseen, jännittyneeseen ja lauenneeseen, joita erottaa toisistansa varsinkin se, että edelliseen liittyy ponnistuksen tunne, joka jälkimmäisestä puuttuu. (Bergson 1958, 145)

Bergsonin sanoissa kokemus toisesta saa merkityksensä, kun se nousee esiin yksilöllisen luovan toiminnan rajojen haastajana. Kokemus toisesta rikkoo elävän yksilön yhtäjaksoisen virtauksen saaden sen hetkellisesti sijoiltaan, sillä toisin kuin omaa toimintaa, toisen toimintaa ei voi ennakoida - vaikka teemmekin jatkuvasti oletuksia toisistamme. Tämä irtaantuminen totutusta haastaa yksilöllistä toimintakeskusta mukautumaan ja löytämään uudenlaisia tapoja muokata ainetta ja yksilöllistä kestoaan. Kokemus toisesta haastaa muovaamaan kehoon tallentuneiden muistojen lisäksi uusia toimintatapoja ja uusia muistoja. Juuri uutta luova toiminta liittää toisiinsa keskenään erilliset toimintakeskukset.

Tässä irtaantumisen prosessissa sekä kunkin henkilön uniikissa historiassa Bergson näkee myös vapauden. Toisen toimintaa, tunteita tai ajattelua ei voi hallita.

\section{Johtopäätökset}

Olemme artikkelissamme tutkineet kokemusta toisesta Bergsonin keston käsitteen avulla ja analysoineet, kuinka juuri kokemus toisesta itsestä erillisenä toimintakeskuksena haastaa yksilöä irtaantumaan omaksi toimintakeskuksekseen sekä suuntautumaan kohti luovaa prosessia. Keston käsitteestä avautuu Bergsonin koko filosofinen metodi tietoisuuden tarkasteluun. Samalla Bergsonin keston käsitteen avulla analysoituna voidaan nähdä, kuinka henkilöiden kokemukset voivat hetkellisesti ikään kuin sulautua yhteen. Tässä yhteen sulautuneessa kestossa yksilöllinen toimintakeskuksemme havaitsee toisen ja myös mahdollisuuden yhteiseen luovaan toimintaan. Nimenomaan kestossa yksilöllinen kestomme pyrkii ponnistellen luomaan uutta sekä säilyttämään muistot menneestä. Bergsonin elämän hyöyn ajatuksen pohjalta voidaan ehkä myös ajatella, että olemme vasta kasvaessamme ja aikuistuessamme oppineet irrottamaan oman ajattelumme toisista.

Kuten olemme argumentillamme osoittaneet, keston käsite Bergsonilla liittyy olennaisesti sekä Bergsonin koko filosofiseen metodiin että moniin muihin hänen filosofiansa keskeisiin käsitteisiin, kuten virtaukseen, liikkeeseen ja muistiin nojautumisena menneeseen ja tukeutumisena tulevaisuuteen. Kestosta tietoiseksi tuleminen taas liittyy toisten toimintakeskuksien kokemiseen. Kuten Deleuze asian ilmaisee, "kesto on olennaisesti muistia, tietoisuutta, vapautta" (Deleuze 2018, 46). Kesto näyttäytyy tietoisuudelle tietynlaisena muistin, kauan tai äsken menneiden hetkien, ansiosta. Tietoisuutta, jolle kesto on, ei edes olisi ilman muistia (Bergson 1959). Va- 
paus taas liittyy muistiin ja kestoon sekä toiseuden kokemukseen.

Bergsonin keston käsite ei ole itsessään välttämättä riittävä analyyttinen väylä kokemukseen toisesta. Tarvitaan myös fenomenologian tuomaa analyysia, minkä jälkeen Bergsoniin voidaan ottaa ikään kuin uusi näkökulma, toinen kierros. Bergsonin ajattelua kenties eniten eksplisiittisesti hyödyntävän ja lähelle tulevan fenomenologin Levinasin $(2012,241,316-317) \mathrm{mu}-$ kaan Bergsonin keston käsite tulee lähelle fenomenologien kehittämää temporaalisuutta. Levinas tulkitsee Bergsonin kestollisen metafysiikan ennakoivan myöhempien fenomenologien ajattelua. Huomion arvoista on kuitenkin Levinasin kriittisyys Bergsonin dualismiin taipuvaa katsantokantaa kohtaan, missä sielu ohjaa ruumiin toimintaa siitä irrallisena. (Levinas 1998.) Levinas myös irtaantuu Bergsonin keston käsitteen jatkuvuudesta ja virtauksesta tulkitsemalla aikaa äärettömyytenä, jossa toisen henkilön kohtaamisesta johtuva haaste asettaa oman kokemuksen totuudesta jatkuvasti kyseenalaiseksi.

Yllä analysoidussa luovassa toiminnassa yksittäinen ihminen kestollisena toimintakeskuksena kantaa jatkuvan muutoksen mahdollisuutta. Palauttaessaan mieleen kokemaansa, käymällä läpi älyllistä toimintaansa uudelleen, hän havaitsee mahdollisuuden muuttaa toimintaansa. Hän voi järjestellä liikettään, haastaa kehoaan ja siten myös ajatteluaan mukautumaan uusiin uomiin. Näin tulisi tapahtua Bergsonin mukaan myös filosofisessa tutkimuksessa.

Filosofia näet ei silloin ole yhden ainoan ajattelijan rakennelma, hänen järjestelmällinen teoksensa. Se sietää, se vaatii alinomaa lisäyksiä ja korjauksia. Se edistyy samoin kuin positiivinen tiede ja on, kuten viimeksi mainittukin, yhteistyön tulos. (Bergson 1958, 8.)

Keston käsite on tarkoitettu jaettavaksi ja yhteisen ajattelun välineeksi, yhteisessä ajattelussa uudelleen tuotettavaksi ja korjattavaksi. Bergsonille toisen kokemuksen kyseenalaistaminen ei ole järjellisesti perusteltua. On järkevämpää ja todennäköisempää, että toinen ihminen ei ole vain minun ajatteluni tulos, vaan osa elämän hyökyä, jonka osa myös itse olen. Esimerkiksi Souleymane Bachir Diagne (2018) hyödyntää ajattelussaan bergsonilaista keston sekä elämän hyökymisen käsitteitä. Diagnen mukaan runoilijafilosofi Muhammad Iqbal ajatteli yhdessä Bergsonin kanssa haastaen länsimaista filosofista traditiota samalla omista lähtökohdistaan. Myös Gilles Deleuzen (2018) Bergsonismi on Bergsonin ajatusten uudelleen suodattamista, mikä tekee Deleuzen bergsonismista kiinnostavan jälkistrukturalistisen ajattelun kehikon. Moyn (2005) kuvaa puolestaan Levinasin tulkintaa Bergsonista todelliseksi bergsonismiksi. Bergsonin metodin ansiona voidaankin pitää sen joustavuutta muutokselle. Se ei ainoastaan tee tilaa toisin ajattelulle, vaan mahdollistaa ajattelun kestollista vaihtelua. Ei ole mielekästä, eikä oikeastaan edes mahdollista toistaa bergsonilaista ajattelua puhtaana muistona, vaan se suodattuu kuhunkin aikaan kunkin ajattelijan oman toiminnallisen keskuksen luovan toiminnan seurauksena.

км кATJA CASTILLO on tohtorikoulutettava sekä yliopisto-opettaja Oulun yliopiston kasvatustieteiden tiedekunnassa.

YTM MINNA-KERTTU KEKKI on tohtorikoulutettava Oulun yliopiston kasvatustieteiden tiedekunnassa sekä asiantuntija Kasvatuksen kehityskeskus Opinkirjossa.

\section{VIITTEET}

1 Levinas nimeää Totalité et Infini -teokselleen vuonna 1987 kirjoittamassaan johdannossa Henri Bergsonin uudistavan työn merkityksen myöhemmille fenomenologeille. Juuri keston käsite nousee keskeiseksi työkaluksi, jolla voitiin irtaantua ajan kiinnittymisestä yksinomaan avaruuteen ja tilaan.

2 Keston käsitteen määritteleminen Bergsonilla on paikoin haastavaa, sillä Bergsonin oma käsitys kestosta muuttuu hänen uransa aikana. Kuten Deleuze (2018) luonnehtii tilannetta, myöhemmissä töissä kesto näyttää Bergsonille yhä vähemmän palautuvan psykologiseen kokemukseen ja muuttuu yhä enemmän olioiden vaihtelevan olemuksen rakenteeksi ja avaa siten kompleksisen ontologian teeman. 
3 "L'artifice de cette méthode consiste simplement, en somme, à distinguer le point de vue de la connaissance usuelle ou utile et celui de la connaissance vraie. La durée où nous nous regardons agir, et oùm il est utile que nous nous regardions, est une durée dont les éléments se dissocient et se juxtaposent; mais la durée où nous agissons est une durée où nos états se fondent les uns dans les autres, etc'est là que nous devons faire effort pour nous replacer par la pensée dans le cas exceptionnel et unique où nous spéculons sur la nature intime de l'action, c'est-à-dire dans la théorie de la liberté." (s. 207208)

4 "Ainsi la matière distingue, sépare, résout en individualités et finalement en personnalités des tendances jadis confondues dans l'élan originel de la vie." (vrt. Henkinen tarmo, s. 26)

5 Tässä yhteydessä nousee mielenkiintoinen kysymys keston jatkumisesta: eri päivät koetaan ikään kuin erillisinä yksikköinä, ajan palasina, koska välillä nukutaan. On täysin eri asia herätä uuteen päivään kuin huomata päivän vain vaihtuneen toiseen osana yhtä ja samaa päivää, jos ei ole nukkunut välissä. Bergsonille kesto ja muisti kuitenkin toimivat monella tasolla: menneisyys ei jossain vaiheessa enää ole osa nykyisyyttä, mutta se vaikuttaa kuitenkin, samoin kuin edelliset hetket, jotka kuitenkin koetaan osana "tätä hetkeä".

6 "Ce que nous percevons en fait, c'est une certaine épaisseur de durée qui se compose de deux parties: notre passé immédiat et notre avenir imminent. Sur ce passé nous sommes appuyés, sur cet avenir nous sommes penchés; s'appuyer et se pencher ainsi est le propre d'un être conscient."

7 "Si donc, dans tous les domaines, le triomphe de la vie est la création, ne devons-nous pas supposer que la vie humaine a sa raison d'être dans une création qui peut, à la différence de celle de l'artiste et du savant, se poursuivre à tout moment chez tous les hommes : la création de soi par soi, l'agrandissement de la personnalité par un effort qui tire beaucoup de peu, quelque chose de rien, et ajoute sans cesse à ce qu'il y avait de richesse dans le monde ?" (vrt. Henkinen tarmo, s. 27)

\section{KIRJALLISUUS}

Paul Ardoin, S. E. Gontarski, and Laci Mattison (2013). Understanding Bergson, Understanding Modernism. Understanding Philosophy, Understanding Modernism. New York: Bloomsbury Academic.

Barnard, William (2011). Living consciousness: The metaphysical vision of Henri Bergson. State University of New York Press, Albany.

Bergson, Henri (1907). L'evolution créatrice. Félix Alcan ja Guillaumin, Pariisi.

Bergson, Henri (1920a). Essai sur le données immédiates de la conscience. Librairie Félix Alcan, Pariisi.

Bergson, Henri (1920b). L'énergie spirituelle: Essais et conférences. Librairie Félix Alcan, Pariisi.

Bergson, Henri (1932). Les deux sources de la morale et de la religion. Librairie Félix Alcan, Pariisi.

Bergson, Henri (1958) Henkinen tarmo. Suom. J. Hollo. WSOY, Porvoo.

Bergson, Henri (1959). "Introduction à la métaphysique". Teoksessa La pensée et le mouvant. OEuvres, Édition du Centenaire. Presses Universitaire de France, Pariisi, s. 392-432.

Bergson, Henri (1972). Mélanges. A. Robinet, toim. Presses Universitaires de France, Pariisi.

Bergson, Henri (2008 [1939]). Matière et mémoire: Essai sur la relation du corps á l'esprit. Kahdeksas editio. Quadrice/Puf, Pariisi.

Deleuze, Gilles (2018). Bergsonismi. Suomentaja Eetu Virén. Tutkijaliitto, Helsinki.

Diagne, Souleymane Bachir (2018). Open to reason: Muslim philosophers in conversation with the western tradition. Kääntäjä Jonathan Adjemian. Columbia university press, New York.

Guerlac, Suzanne (2006). Thinking in Time: An introduction to Henri Bergson. Cornell University Press, Ithaca ja Lontoo.

Heidegger, Martin (2006). Sein und Zeit. Max Niemeyer Verlag Tübingen, Tübingen.

Hokenson, Jan Walsh (2013). "Comedies of Errors: Bergson's Laughter in Modernist Contexts”. Teoksessa Understanding Bergson, Understanding Modernism, Paul Ardoin, S. E. Gontarski, Laci Mattison (toim.). Bloomsbury Academic, New York, s. 38-53.

Husserl, Edmund (1907). Ding und Raum. Husserliana vol. 16. Claesges, Ulrich (toim.). Den Haag, Nijhoff.

Husserl, Edmund (1954). Die Krisis der europäischen Wissenschaften und die transzendentale Phänomenologie. Husserliana vol 6. Biemel, Walter (toim.). Den Haag, Nijhoff. 
Husserl, Edmund (1973). Zur Phänomenologie der Intersubjektivität: Zweiter Teil: 1921-1928. Husserliana vol. 14. Kern Iso (toim.). Nijhoff, Den Haag.

Husserl, Edmund (1976) [1913]. Ideen zu einer reinen Phänomenologie und phänomenologischen Philosophie. Erstes Buch: Allgemeine Einführung in die reine Phänomenologie. Karl Schuhmann, toim. Den Haag, Nijhoff.

Kelly, Michael R. (2010). "Introduction". Bergson and Phenomenology. Kelly, Michael R. (toim.). Palgrave Macmillan, Hampshire, New York.

Lacey, A.R. (1999). Bergson. Routledge, Taylor \& Francis Group, Lontoo ja New York.

Landes, Donald (2012). "Translator's Introduction". Teoksessa Phenomenology of Perception, Maurice Merleau-Ponty, kääntäjä Donald Landes, s. xxx-1.

Lawlor, Leonard (2010). "Intuition and Duration: an Introduction to Bergson's 'Introduction to Metaphysics'”. Bergson and Phenomenology. Kelly, Michael R. (toim.). Palgrave Macmillan, Hampshire, New York. 25-41.

Lefebvre, Alexandre (2017). "Bergson, human rights, and joy". Continental Philosophy Review vol. 50, s. 201-223.

Lefort, Claude (1974). "Maurice Merleau-Ponty". Histoire de la philosophie, III. Du XIXe siècle à nos jours, Encyclopédie de la Pléiade, 174. Éditions GALLIMARD: Pariisi. 692-706.

Levinas, Emmanuel (1996a). Meaning and Sense. Peperzak, Adriaan T., Critchley, Simon ja Bernasconi, Robert (toim.) Basic philosophical writings. Indiana University Press, Bloomington ja Indianapolis. 33-64.

Levinas, Emmanuel (1996b). Transcendence and Intelligibility. Peperzak, Adriaan T., Critchley, Simon ja Bernasconi, Robert (toim.) Basic philosophical writings. Indiana University Press, Bloomington ja Indianapolis. 149-159.

Levinas, Emmanuel (1998) Discovering existence with Husserl. Kääntäjät Richard B. Cohen ja Michael B. Smith. Northwestern University Press, Illinois.

Levinas, Emmanuel (2007 [1969]). Totality and Infinity. An essay on exteriority. Kääntäjä Alphonso Lingis. Duquesne University Press, Pittsburgh, Pennsylvania.

Levinas, Emmanuel (2012 [1961]). Totalité et infini: Essai sur l'éxtériorité. Le Livre de Poche.

Dordrecht Boston London, Kluwer Academic Publisher.

Lipps, Theodor (1893). Grundtatsachen des Seelenlebens. Cohen, Bonn.

Lipps, Theodor (1898). Komik und Humor: Eine psychologisch-ästhetische Untersuchung. L. Voss, Hampuri.

Luft, Sebastian ja Overgaard, Søren, toim. (2012). The
Routledge Companion to Phenomenology. Routledge, Lontoo, New York.

Massey, Heath (2015). The Origin of Time: Heidegger and Bergson. SUNY Press, Albany.

Merleau-Ponty, Maurice (1945). Phénoménologie de la perception. Éditions Gallimard, Pariisi.

Moyn, Samuel (2005). Origins of the Other: Emmanuel Levinas between Revelation and Ethics. Cornell University Press, Ithaca.

Mullarkey, John (2013). ”Bergson and the Comedy of Horrors". Teoksessa Understanding Bergson, Understanding Modernism, Paul Ardoin, S. E. Gontarski, Laci Mattison (toim.). Bloomsbury Academic, New York, s. 243-255.

Pitts, Andrea ja Westmoreland, Mark William (2019). Beyond Bergson: Examining race and colonialism through the writings of Henri Bergson. State University of New York Press, Albany, New York.

Stein, Edith (2008) [1917]. Zum Problem der Einfühlung. ESGA 5. Herder, Freiburg.

Szanto, Thomas ja Landweer, Hilge, toim. (2020). The Routledge Handbook of Phenomenology of Emotions. Routledge, Lontoo, New York.

Waldenfels, B. (2009) Ortverschiebungen, Zeitverschiebungen. Suhrkamp, Frankfurt am Main. 